\title{
ADDITIONAL ARCHIVES OF THE YATOI
}

\author{
BY CLARK L. BECK, JR. AND ARDATH W. BURKS
}

Mr. Beck is Manuscripts Librarian of Special Collections and Archives in Alexander

Library and Dr. Burks is Professor Emeritus of History at Rutgers University

\section{$\mathrm{F}$}

TOR some time scholars have realized that it would be difficult to treat modern Japanese relations with the West, more particularly, Japan's contacts with America, without a visit to New Brunswick. This is true because of the location of the Griffis Papers in the Department of Special Collections and Archives of the University Libraries.

The presence of the Griffis Papers at Rutgers University was in turn the product of the experience and interest of a remarkable individual, as well as of a fortuitous relationship between Rutgers and Japan during the nineteenth century. The individual was, of course, William Elliot Griffis (I 843-I 928, Rutgers Class of I 869), ' who was doubtless America's first "old Japan hand." The relationship was technically between the Rutgers Grammar School (now Rutgers Preparatory School), ${ }^{2}$ Rutgers College (now part of Rutgers University), and a feudal domain, Echizen (modern Fukui Prefecture). ${ }^{3}$ The ties began in the 1860 , when a band of samurai (with assumed names to hide their illegal exit from Japan) arrived to study English and then to transfer into college-level work at Rutgers.

In our day, thanks to the work of American and Japanese scholars and to the generosity of Japanese philanthropy, the original Griffis Papers have been greatly augmented and the significance of this resource greatly enhanced. On December 6, I 980 in the Alexander

'Ardath W. Burks, "William Elliot Griffis, Class of I 869," The Journal of the Rutgers University Libraries, XXIX.3 (Bicentennial Issue, September 1966), pp. 9I-IOO. See also Edward R. Beauchamp, An American Teacher in Early Meiji Japan (Honolulu: The University Press of Hawaii, 1976). Professor Beauchamp has worked in the Griffis Papers.

2 In the nineteenth century Rutgers Grammar School occupied what is now called Alexander Johnston Hall, which houses the Rutgers News Service. More recently the successor, Rutgers Preparatory School, moved out to its river campus on Easton Avenue.

${ }_{3}$ Ties between the two communities have been revived in modern times: in October $198 \mathrm{I}$ in Fukui, Dr. Edward J. Bloustein, President of Rutgers, signed an exchange agreement with President Igarashi Tadao of Fukui University; in May 1982 in New Brunswick, Mayor Ohtake Yukio of Fukui City signed a covenant with Mayor John Lynch of New Brunswick. Note: Throughout this article, Japanese proper names appear as they would in Japan, i.e., the surname precedes the given name. 
Library, during a symposium marking the formal opening of an exhibition based largely on the Griffis Papers, ${ }^{4}$ President Edward J. Bloustein of Rutgers offered words of gratitude to Ambassador Takahashi Shotaro, representing Japan. The occasion marked also the beginning of activities supported by a grant from The Commemorative Association for the Japan World Exposition, I 970 (JEC Fund), ${ }^{5}$ designed to aid in the expansion of resources around the core Griffis material.

It is now safe to say that, owing to Japanese support and to the efforts of many individuals-Japanese and Westerners-it is no longer possible seriously to study the process of modernization in Japan, specifically the counsel and aid lent to Japanese by foreigners in the nineteenth century, without consulting the Griffis Papers and related primary documents.

In brief historical summary, the Griffis Papers became available for public research in 1928 when, just after Griffis' death, his extensive collection of correspondence, publications, reprints, notes, clippings, draft manuscripts, and Japanese memorabilia were forwarded to the Library. Griffis, it should be remembered, during a post-graduate year at the New Brunswick Theological Seminary, tutored some of the first Japanese students at Rutgers Grammar School and at Rutgers College. In I $87 \mathrm{I}$, on the invitation of the Lord of Echizen, Matsudaira Shungaku, he spent almost a year in Fukui, ". . . alone in a daimio's capital far in the interior, away from Western influence, when feudalism was in its full bloom, and the old life in vogue."6 After his Fukui stay, Griffis was transferred to Tokyo, where he taught until July I 874 . After his return to America and until he made a second, his last, visit to Japan in I 927, The Rev. William E. Griffis became undoubtedly the most influential writer in projecting impressions of Japan on the minds of his informed contemporaries. ${ }^{7}$

${ }_{4}^{4}$ Exhibit and catalogue prepared by Clark L. Beck and Ardath W. Burks, As wE Saw THEM; Westerners Interpret Japan, 1853-1912 (New Brunswick: Rutgers the State University of New Jersey, 1980). The event was made possible by generous support from the New Jersey Committee for the Humanities, the Friends of the Rutgers University Libraries, the Consulate-General of Japan-New York, and the Committee on Asian Studies.

5 Formally established on September I, I97 I, the JEC Fund has provided grants and subsidies for endeavors in cultural exchange. The Fund has become well known in the United States for its support of library collections which specialize on Japan.

${ }^{6}$ W. E. Griffis, The Mikado's Empire (New York: Harper \& Bros., 6th ed., I890), p. 9 .

J John Whitney Hall, A. Whitney Griswold Professor of History at Yale University, has 
It is also a fact that Griffis, the amateur historian, began the systematic study of the so-called "employed foreigners," those who aided Japan in the process of modernization in the late nineteenth century. They have since been referred to as the pre-Peace Corps peace corpsmen, the "live machines" who preceded contemporary technical assistants by almost a century. Hazel Jones, who has done research in the Griffis Papers, has estimated that foreigners lent the new Meiji government some 9,500 man-years of service. ${ }^{8}$ It is, of course, to define a series of fascinating historical problems to ask, how effective were they? Were they "cultural imperialists," or did Japanese control the process of exchange? What impressions of Japan did these first "old Japan hands" convey to their countrymen in the West?

In order to interpret primary documents accurately, one must bear in mind the limitations of their creators. Such caution is especially advisable when studying the yatoi. What the hired foreigner could not understand (or at least began to grasp only after considerable experience) was the environment into which he found himself plunged. The typical alien carried in his baggage all the prejudices of a sense of cultural superiority. He bewailed the effects of Japan's isolation (before his timely arrival), the traces of "nonWestern," "un-Christian," "backward and feudal" society (before it was "Westernized"). Even the intelligent foreigners (Griffis, Morse, Guido Verbeck, and Ernest Fenellosa, for example) displayed ambivalence on occasion, between denunciation of and admiration for the Japan before Perry. To an extent, all thus shared the tendency to exaggerate their roles in the modernization of Japan. Griffis himself wrote an early, ethnocentric piece, "The Makers of Modern Japan," which dealt only with the Americans' contributions and which fortunately was never published. ${ }^{9}$

Upon their arrival at the Library, it was discovered that the

nominated Griffis' volume, The Mikado's Empire, as the single most influential book on Japan published prior to World War I.

${ }^{8}$ The foreign advisers were known in Japanese as yatoi, literally, "hired help"; or more formally, as oyatoi gaikokujin, the "employed foreigners." They assisted the new government, established in I 868 and named after its young ruler, the Meiji Emperor (the Meiji era lasted from I 868-I 9 1 2). See H. J. Jones, Live Machines: Hired Foreigners and Meiji Japan (Vancouver: University of British Columbia Press, 1980), p. 7. Professor Hazel Jones, now of the University of Alberta, has worked in the Griffis Papers.

9 W. E. Griffis, "Four Makers of Modern Japan" (unpublished ms.), The Griffis Papers, Department of Special Collections and Archives, Alexander Library. 
Griffis Papers contained items identified with other Rutgers men. For example, there were papers of Dr. David Murray (I 830-I 905) who, following Griffis, went out from the Rutgers faculty to aid the new government in the establishment of a modern educational system. There were also memorabilia from Griffis' friend and classmate, Edward Warren Clark (I85 I-1907), who taught in Shizuoka. ${ }^{\circ}$

In the contemporary era, the first inventory of the Griffis Papers was in fact made by a graduate student from Columbia University. ${ }^{\text {I }}$ In the post-World War II period, the first published survey was carried out by one of the authors, with the help of a Rutgers graduate student. ${ }^{12}$ Shortly thereafter occurred one of those thrilling finds that are, on the one hand, delightfully unplanned and, on the other, so characteristic of academic pursuits.

In I963-I964 and I964-I965, a Japanese graduate assistant, Kaneko Tadashi (now a distinguished staff researcher in the $\mathrm{Na}$ tional Institute for Educational Research, Tokyo), was pursuing doctoral-level work in the Rutgers Graduate School of Education. Kaneko was reading and wrote on Dr. Murray. Meanwhile, he was supporting himself by part-time work on the Griffis Papers, under the direction of the authors. On a small grant designed to give him a travelling vacation, between terms, in California by chance he met a granddaughter of Griffis, Mrs. Katherine G. M. Johnson. The net result was an increase in the size of the Griffis Papers by about 30 percent. Mrs. Johnson donated some of her personal papers, the journal kept by Griffis while in Fukui, ${ }^{13}$ scrapbooks, and letters written by Griffis to his sister ("Maggie"), all to the Library.

The Griffis Papers were further expanded in 1978, when the two authors led and accompanied a delegation of Rutgers alumni

1o One of the documents most in demand by Rutgers alumni and friends is The Rutgers Graduates in Japan, an address delivered in Kirkpatrick Chapel, Rutgers College, June I6, I 885 by William Elliot Griffis, revised and enlarged and republished at the I 50 th anniversary of the College (New Brunswick: Rutgers College, I9 16), 36 pp.

" [Frederick Weldon], "Report to the American Council of Learned Societies on the W. E. Griffis Collection at Rutgers University, New Brunswick, New Jersey" (n.d. [1 940]), typed ms., 7 pp. See also Frederick Weldon, "Hashimoto Sanai: A Japanese Martyr," The Journal of the Rutgers University Library, IV. I (December 1940), pp. I 5-2 I.

${ }^{12}$ Ardath W. Burks \& Jerome Cooperman, "The William Elliot Griffis Collection," The Journal of Asian Studies, XX. I (November 1960), pp. 61-69.

${ }^{13}$ The journal has been translated into Japanese by a young scholar in Fukui; see Yamashita Eiichi, Gurifuisu to Fukui (Griffis and Fukui) (Fukui: 1979). 
on a trip to Japan, including a memorable visit to Fukui. One of the authors, an archivist, remained behind in Fukui to work out exchange procedures with local colleagues, specifically with librarians at Fukui University, at the Fukui Prefectural Library, and at the Fukui City Local History Museum. These visits were made possible in large part by support from the Rutgers Research Council in the form of a "grant-to-obtain-a-grant."

Award of the JEC Fund Grant (in I 980) made possible a further, sharp increase in acquisitions. One of the authors, in Tokyo in I 980 to attend an international congress, spent a week in a reconnaissance-inventory of many of the sources and materials described below. In this task he was greatly assisted by Fujimoto Hiroshi, who had just completed a Master of Arts (History) degree at Rutgers. During the fiscal year I980-I98 I, the authors supervised the acquisition of materials in Japan, actually collected some of the papers in the United States, and expended the total of JEC Fund monies.

It must be understood that, in the cases of most of these acquisitions, photo-copies were made, since the original could not, of course, be transferred. The presence of these copies alongside and in support of the original Griffis materials makes the resource unique in the world. ${ }^{14} \mathrm{~A}$ scholar would have to visit many collections in America (including the Griffis Papers) as well as abroad to see all of the original documents. Thus it would still be necessary to visit and dip into the archives of the Foreign Ministry, in Azabu, in Tokyo; into the materials housed in the Yokohama City Historical Compilation library (on the site where Commodore Perry signed for the United States the first treaty with Japan); into the papers of Horace Capron (1804-1 885) at Yale or the materials on William S. Clark (1 826-I 886) at the University of Massachusetts. And it would always be a pleasure to visit the Phillips Library of the Peabody Museum in Salem, Massachusetts, to see the original papers left by Edward Sylvester Morse (1838-1925). The most convenient place to begin, however, is now the Griffis Papers and allied collections at Rutgers.

The newly acquired documents range from general and extensive

${ }^{14}$ With regard specifically to the Rutgers-Fukui connection, the Fukui University Library may soon match the holdings of Rutgers. For two summers, I 98 I and 1982, professors and librarians from Fukui have been photo-copying documents in the Alexander Library. 
materials on, for example, almost all the foreign employees of Meiji Japan, over to quite specific papers of an individual. A very few items purchased during I980-I98 I are originals, three rare maps, for example. ${ }^{15}$ The remainder are copies, usually consisting of microfilm rolls, and occasionally, photo-copies.

To understand the milieu of Japan in transition from the twilight of the Tokugawa era (I600-I 867) to the dawn of modern, Meiji Japan (1868-I912), one could, of course, concentrate on the center of power. There is a voluminous literature, both in Japanese and, surprisingly, in English, about the regime of the shogun in Edo (modern Tokyo). Or one could, with rich rewards, dip into extant sources on regional societies, local regimes, and the cultures of the celebrated castle-towns. Understandably, therefore, in the recent acquisitions Special Collections and Archives has reached out to collect materials on one local region, one regime, and one castletown. This is Fukui, to which Griffis repaired on the very eve of the collapse of the old orders and the rise of the new. ${ }^{16}$

The search thus started with materials on the local history of Echizen domain (modern Fukui). With the published works of "The Old Reformer," Matsudaira Keiei (best known as Shungaku) already on the Rutgers Library shelves, ${ }^{17}$ the prime target became selected unpublished documents. These included materials from the Fukui Prefectural Library centering on the Matsudaira documents, for example, "An Inquiry into the Flowering of old Fukui Education." Also located and copied were reports on the Meidokan and the Meishinkan, domain academies which Griffis found astonishingly advanced. ${ }^{18} \mathrm{~A}$ third source copied was part of the Yagi family

is (Originals) i 87 I Map of Japan; i 859 Map of Tokyo; i 855 -1 860 Road Map [of Japan]. Each measures several square feet and two are richly hand colored.

${ }^{16}$ Griffis arrived in Japan during the period which the Japanese call bakumatsu ("the end of the bakufu"). The bakufu, or military headquarters of the Tokugawa shogun (military dictator), was in Edo (today called Tokyo). Echizen-han (the domain) was under the wise guidance of a daimyo (lord), Matsudaira Shungaku (1 829-1 890). His enlightened administration saw steady gains in the field of education and he was instrumental in the decision to invite a foreign expert-teacher to the domain, to aid in the introduction of Western science.

17 Matsudaira Shungaku zenshu (Complete works of Matsudaira Shungaku), in the Meiji Centennial Historical Series (Tokyo: 1973), 3 vols.

${ }^{18}$ Fukui Kenritsu Toshokan (Fukui Prefectural Library), Matsudaira bunko (Matsudaira library), 2 microfilm rolls. Incidentally, acquisitions of copies of such original materials will offer a challenge to a generation of students of Japanese. Although the photocopies are quite clear, many of the original documents were prepared in archaic, formal language and written in "grass script" (sosho). Many contemporary graduates of Japanese universities have difficulty in reading this script. 
archives, including the only biography of a young samurai who became a Rutgers man and, after his death, a cultural hero, Kusakabe Taro. ${ }^{19}$

A much larger quantity of documents was copied from the Fukui University Library, which had access also to materials in the Fukui City Local History Museum. Some forty-eight sources were selected, including: a four-volume, 567-page history of Fukui Prefecture; a local history time chart prepared by the local history museum; materials on the Asakura family (who first settled the Fukui region in the early fourteenth century); documents relating to Echizen domain under the Matsudaira, who were a family collateral to the Tokugawa shogun; geographic monographs, gazeteers, and maps. ${ }^{20}$

With the aid of such resources, the scholar can now (as Griffis could not in the nineteenth century) trace most of the employed foreigners who worked for the new Meiji government. Moreover, now one need not go to Tokyo to do so. Special Collections and Archives now contains copies of basic materials housed in the Foreign Ministry Archives, in Azabu, in Tokyo. These contain indices, tables, and lists of foreigners employed at all levels of Japan's government; in many cases, specifications, salary schedules, and contracts between the Foreign Ministry and the yato $i$; some correspondence (in Japanese, Dutch, French, German, and English) between parties; and even lists of aliens in private employment. ${ }^{21}$

Through the Foreign Ministry archives march the familiar figures in the drama of Japanese-Western relations in the nineteenth

${ }^{19}$ Kusakabe Taro (his original samurai family name was Yagi; I845-1870) first studied Dutch in Nagasaki. He arrived in New Brunswick in 1868 and there Griffis tutored him in Latin. In 1870 , just before his graduation, Kusakabe died of tuberculosis. Griffis attended his funeral and later, when he arrived in Fukui, delivered Kusakabe's diploma and Phi Beta Kappa key to the bereaved family. Kusakabe has two graves: one is in New Brunswick in Willow Grove Cemetery (now restored with the help of Japanese contributions), and one in a quiet Buddhist temple in Fukui. The biography was written by Nagai Tamaki, Kusakabe Taro den (Biography of Kusakabe Taro) (Fukui: I 930), and found in Fukui Kenritsu Toshokan (Fukui Prefectural Library), Yagi bunko (Yaki library), Shin Nihon no senkusha (Outriders of the new Japan), I microfilm roll.

${ }^{20}$ See Fukui Daigaku (Fukui University), Kyodo shiryo mokuroku (Index of local history materials) (Fukui: I 976), I66 pp., from which the 48 selections were identified. Among the copies obtained were: Fukui Shiritsu Kyodo Rekishikan (Fukui City Local History Museum), Shiryo mokuroku (An index of materials); and Fukui-ken shi (A history of Fukui Prefecture), 4 vols. The 48 items occupy Io microfilm rolls.

${ }^{21}$ Gaiko Shiryokan (Foreign Ministry Archives), Gaimusho kiroku (Foreign Ministry records), Kaku shocho fuken gaikokujin kanyatoi ikken (Index of foreign employees in various ministries, agencies, and prefectures) (Meiji 2 [ I 869]), I microfilm roll. 
century. There are the diplomats: among others Sir Harry Parkes (Great Britain), chiefs of the French Legation, Yokohama, and of the Naval Mission, Yokosuka, and Charles DeLong (American Minister). On the Japanese side appear such names as Mori Arinori, Kuroda Kiyotaka, Inoue Kaoru, Iwakura Tomomi, and Okuma Shigenobu. And there are, of course, the foreign employees, ranging from François Coignet (in Japan I 868- I 877), who was the first yato $i$ hired by the regime, through the Americans (Griffis, Murray, Morse, Capron, Clark, and many others), the Dutch, the French, the British, and the Germans, over to the last of the hired foreigners toward the end of the century. Hazel Jones, painstakingly eliminating duplication, has identified some 2,050 individuals by name. ${ }^{22}$

In the process of acquisition, copies of documents chosen from the Tokyo Metropolitan Government Historical Institute were made as well. These include lists of foreigners resident in Edo (later, Tokyo); of those employed in higher education; and of those in private status, for example, hired by the Mitsubishi Company, missionaries, and teachers. ${ }^{23}$

In November I 982, one of the authors visited the newly opened library of the Yokohama City Historical Compilation, to run down copies of additional materials. It is expected that these will reveal such details, for instance, as residence plots, special police provisions to protect aliens, contracts and correspondence relating to the original foreign settlement on the Yamate Bluff in Yokohama.

The remainder of the acquisitions under the JEC Fund grant relates to individuals, their careers, and their records. They represent an interesting variety in professions (an engineer, a scientist, a teacher, and a diplomat); in the nature of the archival format (complete journals, correspondence, and memorabilia); and in time span (two from the early Meiji period, I 868-I874; two from the end of the era, I 900-19I2).

In the case of one archival find, it can safely be said that Special Collections and Archives moved to serve not only its library interests, but also those of the Japanese, as well as of scholars working on Japan throughout the world. In I980, at the time of the exhi-

22 Gaiko Shiryokan (Foreign Ministry Archives), Gaikokujin yatoi nyumei (Table of foreign employees) (Meiji 3 [I870]), I microfilm roll.

${ }_{23}$ Tokyo-to Kobunshokan (Tokyo Metropolitan Government Historical Institute), Kanyatoi gaikokujin kanriroku (Control lists of government foreign employees) (Meiji 16 [1883]), 3 microfilm rolls. 
bition-symposium described previously, the authors were made aware of an unusual opportunity. Professor Fujita Fumiko (now teaching in Tsuda College, Tokyo) had participated in the symposium and had informed Special Collections and Archives that she had discovered an untapped collection of original materials in Northampton, Massachusetts. In June I 98 I, the authors visited the Forbes Library and confirmed the value of the collection.

The materials in Northampton are the personal papers of Benjamin Smith Lyman (1835-1920), a geologist and mining engineer who worked in Japan, particularly in Hokkaido, in the period I 873-1 880. They consist of correspondence, field notebooks, journals, photographs, and even his original contract with the Japanese government. ${ }^{24}$ The bulk of the papers are in a form familiar to many archivists, letterpress copybooks. Such copybooks, which preceded carbon paper, are made up of the remaining yellowish, soft, translucent paper on which brownish impressions were left when blotted on to the originals before their ink dried. The secondary copies are at the point of extinction, when they would be lost to the scholarly world. By direction of Special Collections and Archives and using advanced techniques, the Northeast Documentation and Conservation Center enhanced the dim sheets, copied them, and salvaged the papers. The Japanese will doubtless greet the recovery with enthusiasm, for the Lyman material is unique. ${ }^{25}$

Perhaps most valuable among the papers are Benjamin Smith Lyman's detailed accounts of successive surveys conducted in remote Hokkaido. His notes reflect experiences of the very first outsiders to visit the region inhabited by Ainu aboriginals. Lyman's assistants were, in fact, the first Japanese to go into, for example, the Ishikari River basin, north of Sapporo. The documents show that Lyman spent the winters at the compound of the Hokkaido Colonization Commission (Kaitakushi) at Shiba, in Tokyo. His letters and notes faithfully record the Tokyo scene at the time. The field notebooks document the activities of the summer months, topographic sur-

${ }^{24}$ Memorandum of a Contract signed by Kuroda Kiyotaka, Kaitak [sic] and B. S. Lyman, n.d. [April I7, I873], photo-copy.

${ }_{25}$ Forbes Library, Northampton, Massachusetts, Benjamin Smith Lyman Papers: letterpress copybooks, October 4, I872-April 4, I882; series "L" field notebooks, Japan, I873I 882 ; unbound letterpress copybook, July 8-November I, I877; Lesley letters, January 2 I, I 867-I 885 ; correspondence, I 893-I 910; photographs of Japan, I 880s-I 900s, 32 microfilm rolls. 
veying and the assaying of mineral deposits in the remote northern island.

Lyman's letters reveal clearly what both Jones and Fujita have described, the difficulties of a foreigner trying to understand a strange culture and resultant mutual tensions. One experienced foreign employee of the era concluded, "everywhere was tension, fatigue, and the cry for relief." ${ }_{26}$ Documents demonstrate that Lyman, like Griffis, became enthusiastic about many aspects of Japanese life. They also show, however, that Lyman was, like Griffis, as often frustrated, suffered from communications failures, and several times threatened to resign.

Copy work on the Lyman papers produced as well some interesting materials on the engineer's experiences other than in Japan. A graduate of Harvard ( I 855 ), he had attended the Imperial School of Mines, Paris, and the Royal Academy of Mines, Freiburg. He maintained a lively correspondence with colleagues in Europe. In the United States, he kept up a regular correspondence with Peter Lesley, his uncle by marriage and the State Geologist of Pennsylvania, as well as with his aunt, Susan Lesley. ${ }^{27}$ Some of Lyman's notes give details of surveys in Western Pennsylvania, in and around Cape Breton Island, in the gold fields of California, and in the Punjab area of India.

An equally fascinating figure of quite a different sort was Edward S. Morse. Trained as a biologist under Louis Agassiz of Harvard, Morse came to specialize on sea creatures, specifically, on the brachiopods. It was the search for examples of the species that eventually took Morse to Japan in three periods of residence (1877, I 878-I 879, I 882-I883). It has been said that he went to Japan because, as an ardent Darwinist, he could not find employment in an American college at the time. It is certainly true that Morse gave the first public lecture on Darwin in Japan (October 6, I 877). A brilliant lecturer, he fascinated Japanese with his ability to illustrate his remarks at the blackboard by drawing with both hands simultaneously. Technically defined, Morse's position was not that

${ }^{26}$ Jones, quoting from Edmund G. Holtham (in Japan I 873-1881), Live Machines, cited, p. 123.

27 The Lesley letters are particularly detailed about the Pennsylvania survey and the field work in India. In a letter dated June I 4, 1870 is one of the best available descriptions of a "hill station" (designed for rest and recreation for foreigners) in the Punjab. Forbes, Lyman Papers, letter to J. P. Lesley, June 14, 1870. 
of "foreign employee" of the government; rather, he was a "hired professor." 28

In addition to his regular assignment, collecting specimens for the Peabody Museum of Salem, Morse lectured at the new Imperial University, Tokyo, began what was to be the institution's first scholarly memoirs devoted to science, and laid down the foundations of Japanese archaeology. On a brief train trip, he discovered the celebrated Omori Shell Mounds, a find that shifted the whole perspective of Japan's ancient history. While traveling, digging, and lecturing, Morse set down the notes for what would eventually be his monumental published travelogue, Japan Day By Day. Meanwhile, using his superb skill as a draftsman, he also recorded in sketches details of Japanese houses, their interiors, joists, walls, doors, and furnishings as well as exteriors, gardens, fences, walls, gates, warehouses, and tools. ${ }^{29}$

Much of the raw material for these publications - as well as notes for scientific papers-were located and copied in the Phillips Library of the Peabody Museum of Salem. Acquisitions included copies of Morse's "Japan Journal" (doubtless the foundation for Japan Day By Day); drafts, textual materials, and original sketches (for his books); letters commenting on his publications; lecture notes; and correspondence relating to Japanese potteries. Morse brought back one of the first collections of Japanese pottery to be seen in America, now housed in the Museum of Fine Arts, Boston..$^{3 \circ}$ Finally, in Salem he built one of the first and greatest collections of artifacts illustrating ethnography. Fortunately, the harvest of his labors has been arranged there for all to see. ${ }^{31}$

Papers relating to the two remaining individuals, Milo Jay Wal-

${ }^{28}$ The Japanese term was oyatoi kyoshi.

${ }^{29}$ Edward S. Morse, Japan Day By Day (Boston: Houghton Mifflin Co., I917); also Japanese Homes and Their Surroundings, with illustrations by the author (Boston: Ticknor \& Co., I 886). Fortunately, this rare volume has been reprinted, with a new introduction by Clay Lancaster (New York: Dover Publications, I 961; paper).

30 Museum of Fine Arts, Boston, Catalogue of the Morse Collection of Japanese Pottery (Boston: Riverside Press, I90 I).

${ }^{31}$ Phillips Library, Peabody Museum of Salem, Edward S. Morse papers: correspondence (Box 8.1); "Japan Journal," i 873 + (Boxes I 4-I 5); drafts, Japan Day By Day (Box 59); lecture notes (Box 87); folio, "A Day Among the Kyoto Potteries" (Box I07); correspondence, selected (from Boxes I 21-I 43), 3 microfilm rolls. In I 977 the Peabody Museum mounted a special exhibition honoring Morse and commemorating the hundredth anniversary of his arrival in Japan. The catalogue borrowed the title of Morse's book, Japan Day By Day, ed. by Money Hickman \& Peter Fetchko (Salem, Massachusetts: Peabody Museum of Salem, 1977), I $98 \mathrm{pp}$. 
rath (I 888-I9I3) and Thomas O'Brien (I842-I933), will offer scholars the opportunity to sample experiences in the period toward the end of the transition, at the close of the Meiji era. Already, by the turn of the century, Japan had leapfrogged from feudal isolation into the promises and perils of modernity. The opening of Japan had led not only to steam trains between Yokohama and Tokyo, red brick buildings on the Ginza, and street lamps in the capital, but also to smoky industries in Osaka, substandard housing in Tokyo, and a formidable Imperial Navy at Yokosuka. The sometimes sharp, sometimes subtle shifts in Japan's society and in Japanese attitudes and behavior were reflected in the papers from the late Meiji era, materials copied from the Bentley Historical Library, the University of Michigan.

Milo Jay Walrath was born the son of a pastor in Central City, Iowa. After schooling there, he entered Hillsdale College, in Michigan. On August 3, I 9 I o he sailed from Victoria, British Columbia on the NYK ship, Awa-maru, arriving in Yokohama on August 25, I9IO. For two years he taught in Doshisha, a university in Kyoto long linked with both Japan's fledgling Christian community and, in America, with Amherst College.

Walrath's acquisitions include copies of a rather detailed diary (I9II-I9I3), some correspondence home, and notes. There are also a marvelous scrapbook of old postcards, a collection of old Japanese bookmarks, and other memorabilia. ${ }^{32}$

In one way Walrath was the American counterpart of the Japanese overseas student Kusakabe Taro, who came to Rutgers and died in New Brunswick. Walrath returned to the University of Chicago in I9 I 3 to pursue work toward his Ph.D. (Acquisitions include his student notes and papers, which clearly reflect his recent experiences in Japan.) On September I, I 9 I 3 Milo Walrath drowned in a boating accident, during an outing on a lake in Michigan. ${ }^{33}$

A quite different figure was His Excellency, Thomas J. O'Brien. A lawyer and Republican politician, O'Brien served as United States Minister to Denmark (I905-I907) and, after his Japan tour of duty, as Ambassador to Italy (I 9 I I-I 9 I3). From I 907 to I 9 I I he served as Ambassador to Japan.

${ }^{32}$ Michigan Historical Collections, Bentley Historical Library, The University of Michigan, Milo Jay Walrath Papers, I microfilm roll.

${ }^{33}$ A sister, Esther Lash, added an introduction to Walrath's diaries (1910-1913) and, in effect also his obituary. Walrath Papers, loc.cit., part 4. 
Acquisitions of copies of the O'Brien material clearly reflect a different status, a different experience, as compared with that of the young, humble Doshisha tutor, Walrath. Scrapbooks faithfully kept by family and staff reveal the pomp and circumstance by then surrounding formal United States-Japan relations. There is a complete folio of news clippings related to O'Brien's appointment ( I 907). Quite intriguing are the photographs, notes, and memorabilia of the voyage out to Japan, when O'Brien accompanied William Howard Taft. Then there is the myriad of formal notes, invitations, acceptances, photographs, and news clippings relating to the ambassadorship in Tokyo. More substantive is a folio of papers on American-Japanese diplomatic relations. ${ }^{34}$

One batch of papers lends an ominous note, reminding the scholar that the Tokyo-Washington axis has always alternated between welloiled, smooth operation and squeaky, rough movement filled with the torque of tension. O'Brien arrived in Tokyo just after the infamous racially discriminatory treatment aimed at Japanese in San Francisco, in 1906. Although the Gentlemen's Agreement (1 907) defused this crisis, Japan and the United States immediately plunged into their first "war crisis." This in turn was defused when, in October I 908 , the potentially threatening visit to Tokyo Bay by the U.S. Fleet turned out to be a friendly exchange visit. Certainly O'Brien's calm handling of the affair contributed to resolution of this crisis.

A final group of O'Brien papers deals with the visits of American, Russian, and British naval components, late in I 908.35 The documents reveal clearly that, despite the idealism of the early visitors, the yatoi, later representatives of the West are successively seized with thorny diplomatic, security, and trade issues involving Japan, problems that continue to the present day.

${ }_{34}$ Michigan Historical Collections, Bentley Historical Library, The University of Michigan, Thomas James O'Brien papers, I microfilm roll. See folio, part 2, "Papers re: JapanU.S. Relations."

35 O'Brien Papers, loc.cit., part 7, "Scrapbook June-December I 908 (Russia, England, and U.S. fleet to Yokohama)." 